His successful achievements at European level brought him to a leading role in the French scientific community. In 1973 he was appointed head of the Centre National de la Recherche Scientifique, the main funding agency for scientific research in France, of which he had been a directorate member from 1963 to 1971 . Though he was not long in this post, his influence was strong. Fundamental reseach was his great love, and he defended it vigorously through years of financial difficulties. He was the architect of better links between basic research and applied research, strengthening their interface (the so-called transfer sciences), and he developed interdisciplinary research, in particular on new sources of energy.

In 1976 he was appointed Délégué
Général à la Recherche Scientifique et Technique. Here at very high governmental level, as earlier at CERN and the CNRS, he was the obvious choice as the man best suited to shoulder the vast responsibilities involved in the organisation of research in France. But his ties with the European scientific community remained very close: at CERN above all, where he was Chairman of the ISR Committee from 1971 to 1973, French Delegate to the CERN Council from 1971, Vice-President of the Council in 1976, and finally its President-elect, looking forward with intense interest to the start of these new duties on 1 January 1978; but also at the European Science Foundation at Strasbourg and in numerous international negotiations in the scientific field.
Well known also outside Europe, he was Chairman of the Commission for Particles and Fields of the International Union of Pure and Applied Physics and, from August 1977, first Chairman of the International Committe for Future Accelerators (ICFA), a body bringing together for the first time representatives of all the regions of the world active in the field of big particle accelerators - the United States, Western Europe, the Eastern European countries and Japan.

Bernard Gregory's work and influence were of lasting value. His was a personality in which intellectual power and dignity were combined with warmth and simplicity. His passing represents a great loss for France and for Europe.

M. Jacob

L. Van Hove

\section{P. A. Sheppard}

Professor P. A. Sheppard, CBE, FRS, the meteorologist, died on 22 October 1977 in his 71st year after some years of failing health. He was respected equally in the academic world and in the political world of scientific affairs.

He left Bristol University in 1929 as a physics graduate to start work at Kew Observatory preparing for the International Polar Year 1932-33 which he was to spend as a member of a small British expedition working in the Northwest Territories of Canada. This led Sheppard to some original ideas on atmospheric electricity and ionisation near the ground but his lifelong specialist interest began a little later when in 1934 he joined a team famous in meteorological history. This was set up by the War Office at Porton to study chemical warfare and led to extensive work on wind, temperature and humidity near the ground and especially their turbulent fluctuations.

In 1939 Sheppard joined Sir David Brunt in the Department of Meteorology at Imperial College and in 1952 succeeded him as professor, a post he held until becoming emeritus professor on retirement in 1974. During Sheppard's time the group at the Imperial College earned a world reputation as by far the most active and comprehensive university meteorological department in Britain-or the whole British Commonwealth for that matter-engaged mostly in research and postgraduate teaching.

Sheppard's specialist researches continued without break after the war and included an expedition in 1953 to Anegada, $18^{\circ} \mathrm{N}$ in the Virgin Islands, where a small group under his leadership made some unique observations of the conditions over the ocean up to some $1 \frac{1}{2} \mathrm{~km}$ height. Precision measure- ments over the waters of Lough Neagh were also obtained, a technically difficult operation spread over a number of years.

In a complex field attracting attention in a growing number of countries including of course the United States and the Soviet Union it is not easy to assign any particular theoretical advance unequivocally to one person but Sheppard was certainly acknowledged as a leading thinker. His forte lay in always stressing physical processes and accurate measurements in a subject much favoured by mathematicians but he did as much as anyone to clarify the applicability to the atmosphere near the ground of the logarithmic variation of wind with height and the associated von Karman's non-dimensional constant with value 0.4 .

As a general meteorologist Sheppard was much interested in the basic importance of his boundary layer studies for the largest scale problems of weather systems and the general circulation-the basis of world climateand in this context showed that the convenient assumption of a turbulent boundary layer of limited thickness (of order $1 \mathrm{~km}$ ) was not a valid approximation when applied to the drag of the wind on the surface. Neither, he thought, was the square law of wind drag in all circumstances, especially over the sea. His talent for lucid analysis and physical interpretation was highly regarded, as exemplified by his Presidential Address of 1958 to the Royal Meteorological Society - a triumph of exposition.

As time went on Sheppard took on wider responsibilities and from 1965-71 was chairman of the Space Policy and Grants Committee of the Science Research Council, most of the time a member of the SRC, and chairman also of the Scientific and Technical Com- mittee of the European Space Research Organisation. These were onerous duties which occupied more of his energies than he had anticipated but he remained a meteorologist primarily and was continuously a member and much of the time chairman of the Meteorological Research Committee which guides the Meteorological Office in its researches. In this capacity he was intimately involved in the whole story of the revolution in weather forecasting from the mainly empirical methods which lasted through the 1940 s to the elaborate computer calculations of the present day using mathematical models of growing sophistication derived entirely from the basic physics and incorporating Sheppard's specialities. Although so far as I know he never made a weather forecast in his life, in the way of duty, and for many years seemed to be working in a corner of the science remote from the main business of meteorology, it was gratifying to see his ideas incorporated in the scientific prediction models of today.

In addition to his CBE of 1963 and his FRS of 1964 Sheppard's honours included an honorary doctorate of Leningrad University, a rare tribute, and Hon. D.Sc. of Bath, the city of his schooldays.

Peter Sheppard, to use the familiar adopted name, had wide cultural and intellectual interests. He was forthright in his opinions and severe in scientific criticism but tempered by a warm and engaging personality. With his wife Phyllis who died in 1975 for him a tragic loss-he shared a love of travel and the countryside, of hospitality, good living and bright conversation. $\mathrm{He}$ will long be remembered with affection throughout his profession in many countries of the world and by a wider circle of friends. He leaves two successful sons. $\quad \boldsymbol{R}$. C. Sutcliffe 